
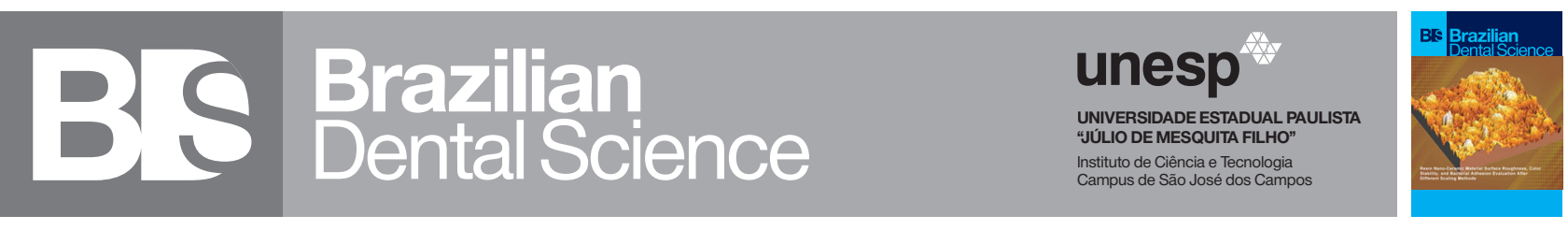

\title{
Fracture Resistance and Strain Analysis of Zirconia Copings With Vertical Knife Edge and Three Horizontal Finish Line Designs; Chamfer, Deep Chamfer and Shoulder With Two Cementation Techniques
}

Resistência à fratura e análise de deformação de copings de zircônia com término cervical em lâmina de faca e três términos horizontais; chanfro, chanfro largo e ombro com duas técnicas de cimentação

\author{
Marwa EMAM$^{1}$, Amr EL-ETREBY ${ }^{1}$, Jihan Farouk YOUNIS ${ }^{2}$ \\ 1 - Fixed Prosthodontics Department, Ain Shams University, Cairo, Egypt. \\ 2 - Fixed Prosthodontics Department, Misr International University, Cairo, Egypt.
}

\section{ABSTRACT}

Objective: The purpose of this in vitro study is to evaluate the effect of four finish line configurations and two cement types on the fracture resistance of zirconia copings. Material and Methods: Forty yttrium tetragonal zirconia polycrystals copings were manufactured on epoxy resin dies with four preparation designs: knife edge, chamfer, deep chamfer $0.5,1 \mathrm{~mm}$ and shoulder $1 \mathrm{~mm}$. The copings were cemented with two cement types (glass ionomer and resin cement); $(n=5)$. Two strain gauges were attached on each coping before they were vertically loaded till fracture with a universal testing machine. Data were analyzed by 2-way analysis of variance ANOVA $(\mathrm{p}<.05)$. Fractured specimens were examined for mode of failure with digital microscope. Results: Knife edge showed the highest mean fracture resistance $(987.04 \pm 94.18)$ followed by Chamfer (883.28 \pm 205.42) followed by Shoulder (828.64 \pm 227.79) and finally Deep chamfer finish line (767.66 \pm 207.09) with no statistically significant difference. Resin cemented copings had higher mean Fracture resistance $(911.76 \pm 167.95)$ than glass ionomer cemented copings (821.55 \pm 224.24$)$ with no statistically significant difference. Knife edge had the highest strain mean values on the buccal (374.04 \pm 195.43) and lingual (235.80 \pm 103.46) surface. Shoulder finish line showed the lowest mean strain values on the buccal (127.47 \pm 40.32) and lingual (68.35 \pm 80.68) with no statistically significant difference. Resin

\section{RESUMO}

Objetivo: O objetivo deste estudo in vitro é avaliar o efeito de quatro configurações de términos cervicais e dois tipos de cimentos na resistência à fratura de copings de zircônia. Material e Métodos: Quarenta copings de zircônia tetragonal policristalina estabilizada por ítrio foram confeccionados em matrizes de resina epóxi com quatro tipos de términos cervicais: lâmina de faca, chanfro, chanfro largo 0,5, $1 \mathrm{~mm}$ e ombro $1 \mathrm{~mm}$. Os copings foram cimentados com dois tipos de cimento (ionômero de vidro e cimento resinoso); $(n=5)$. Dois extensômetros foram fixados em cada coping antes de serem carregados verticalmente até a fratura com uma máquina de teste universal. Os dados foram analisados por análise de variância ANOVA 2 fatores $(\mathrm{p}<0,05)$. Os espécimes fraturados foram examinados quanto ao modo de falha com microscópio digital. Resultados: A Lâmina de faca apresentou a maior média de resistência à fratura $(987,04 \pm 94,18)$ seguida pelo Chanfro $(883,28$ $\pm 205,42)$, pelo Ombro $(828,64 \pm 227,79)$ e finalmente o Chanfro largo $(767,66 \pm 207,09)$, sem diferença estatisticamente significativa. Os copings cimentados com cimento resinoso apresentaram maior média de resistência à fratura $(911,76 \pm 167,95)$ em relação aos copings cimentados com ionômero de vidro (821,55 \pm 224,24 ), sem diferença estatisticamente significativa. A lâmina de faca apresentou os maiores valores médios de deformação na superfície vestibular $(374,04 \pm 195,43)$ e lingual $(235,80 \pm 103,46)$. O término em ombro apresentou os menores valores médios de deformação na superfície vestibular $(127,47 \pm 40,32)$ e lingual $(68,35$ $\pm 80,68)$, sem diferença estatisticamente significativa. Os copings cimentados com resina apresentaram maiores 
cemented copings had higher buccal (295.05 \pm 167.92) and lingual (197.38 \pm 99.85$)$ mean strain values than glass ionomer copings (149.14 \pm 60.94) and $(90.27 \pm 55.62)$ with no statistically significant difference. Conclusion: Vertical knife edge finish line is a promising alternative and either adhesive or conventional cementation can be used with zirconia copings.

\section{KEYWORDS}

Cementation; Flexural strength; Prosthodontics; Tooth preparation; Zirconium. valores médios de deformação na superfície vestibular $(295,05 \pm 167,92)$ e lingual $(197,38 \pm 99,85)$ do que os copings cimentados com ionômero de vidro $(149,14 \pm 60,94)$ e $(90,27 \pm 55,62)$, sem diferença estatisticamente significativa. Conclusão: $O$ término cervical em lâmina de faca é uma alternativa promissora e a cimentação adesiva ou convencional pode ser usada na cimentação de copings de zircônia.

\section{PALAVRAS-CHAVE}

Cimentação; Resistência à flexão; Prostodontia; Preparo do dente; Zircônio.

\section{INTRODUCTION}

A $s$ all-ceramic restorations when placed in the posterior region, had a history of being prone to fracture, strong ceramic core materials have been developed to support the weaker veneering ceramic materials [1,2]. Zirconia $\left(\mathrm{ZrO}_{2}\right)$ has been introduced as a promising metalfree core structure for fixed prostheses due to its superior physical and mechanical properties, chemical stability, and excellent biocompatibility [3]. The material's high flexural strength of 900 megapascals (MPa) to $1200 \mathrm{MPa}$ [4] is due to its unique property to stop the crack propagation "self healing", the tensile stress generated by the crack induces a change from a tetragonal $\mathrm{T}$ configuration to a monoclinic $\mathrm{M}$ configuration with localized volume increase of 3\% to 5\%. The energy is dissipated in the T-M transformation and stops the further advancement of the crack and increase the resistance to further crack propagation [4-10]. The rapid diversification in equipments and materials available for fabrication of computer-aided design/computeraided manufacturing (CAD-CAM) prostheses along with an increase in the availability of dental laboratory processed CAD-CAM restorations is driving the use of $\mathrm{ZrO}_{2}$ copings and framework materials. The relatively high stiffness and good mechanical reliability of partially stabilized $\mathrm{ZrO}_{2}$ allows for thinner core layers, longer bridge spans, and the use of all-ceramic fixed partial dentures (FPDs) in posterior locations [11,12]. Modern adhesive technologies and ceramic materials with enhanced fracture toughness may facilitate the development of minimally invasive preparation designs which help preventing tooth weakening and pulp irritation [13,14]. When $\mathrm{ZrO}_{2}$ was introduced, its fabrication guidelines were copied from metal ceramic systems [15]. Recommended values for cervical finish line varies from 0.5 to $1.2 \mathrm{~mm}$ deep chamfer or shoulder with rounded internal angle [16-20]. Tooth preparations without a defined finish line may be termed vertical preparations as opposed to horizontal ones [21]. The knife edge (KNE) finish line is considered the most conservative for sound tooth structure [19], its most common indications are periodontally involved teeth, [22] endodontically treated teeth, vital teeth in young individuals, and teeth affected by caries at the cervical third of the clinical crown [23]. The concept of minimally invasive dentistry and the superior mechanical properties of $\mathrm{ZrO}_{2}$ allow clinicians to reconsider preparation guidelines such as reducing the coping thickness from $0.5 \mathrm{~mm}$ to $0.3 \mathrm{~mm}$ and changing finish line preparations from shoulder to chamfer or even $\mathrm{KNE}$ margins [24,25]. $\mathrm{ZrO}_{2}$ restorations have high fracture resistance FR and can be cemented with conventional methods recommended by the manufacturers [26]. However, resin bonding between a dental substrate and a restoration 
is advocated for improved retention, marginal adaptation, and inhibition of secondary caries $[27,28]$. On the other hands polycrystalline ceramics lack the ability to be etched thus compromizing the bond strength with cements [29]. To date, combined surface treatment with airborne particle abrasion (50 $\mu \mathrm{m}$ alumina particle size and maximum 2.5 bar pressure) and a specific adhesive monomer with a hydrophobic phosphate monomer have proved reliable for bonding to $\mathrm{ZrO}_{2}$ ceramics [30-32].

There's evidence in the literature that the strength of the ceramic restoration is increased when bonded to the available tooth tissue [33]. Various techniques have been used to evaluate the stress and strain state in dental structures, including holographic interferometry, twoand three-dimensional photoelasticity, finite element analysis and strain gauge techniques [34-37]. Regarding the behavior of restored teeth under a functional load, stress was found to be concentrated at the cervical site [38]. Such localized stress concentrations are probably the initial sites of cement failure [39].

The purpose of this study was to evaluate how finish line preparations, and different cementation techniques influenced the resulting strain and fracture resistance of in vitro zirconia copings. This study tested a twofold null hypothesis, that neither the the finish line design nor the cement type will affect the fracture resistance of cemented $\mathrm{ZrO}_{2}$ copings.

\section{MATERIAL AND METHODS}

\section{Dies fabrication:}

Four master stainless steel dies were milled. They all had the same dimensions of 5.5 $\mathrm{mm}$ crown height, $8 \mathrm{~mm}$ gingival diameter, 6 degrees taper [40] except of different finish line configuration; [41] knife edge finish line (KNE), chamfer finish line with $0.5 \mathrm{~mm}$ thickness $(\mathrm{CH})$, deep chamfer finish line with $1 \mathrm{~mm}$ thickness $(\mathrm{DCH})$ and shoulder finish line with $1 \mathrm{~mm}$ thickness (S). A $45^{\circ}$ occlusal bevel was made to allow core orientation and act as antirotational feature and wide base was fabricated to the master dies for stability purposes (Figure 1). Each die was mounted with its long axis perpendicular to the top surface of a $17 \mathrm{~mm}$ diameter plastic mold filled with polymethyl methacrylate polymer cold cure material (Acrostone, Cold cure, Cairo, Egypt) using a precision surveyor (Paraflex, Bego, Bremen, Germany). An addition curing vinyl polysiloxane duplicating material (Dupliflex, Protechno, Girona, Spain) was used for impression taking of each master die, the impressions were then poured with Epoxy resin (Kemapoxy 150 transparent, CMB, Cairo, Egypt) [40] to fabricate 40 identical resin dies $(\mathrm{N}=40)$. The resin dies were allowed to polymerize for 24 hours [42] at least before separating the dies from their impression.

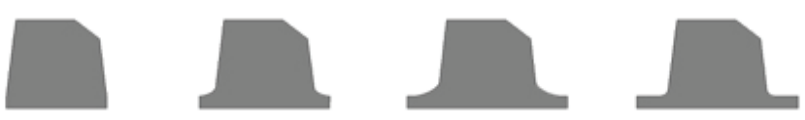

Figure 1- Schematic drawing of the master dies showing their finishline configuration and antirotational feature. a: Knife edge, b: Slight Chamfer $(0.5 \mathrm{~mm})$, c: Deep Chamfer $(1 \mathrm{~mm})$ and d: Shoulder (1 mm).

\section{Construction of zirconia copings:}

Forty Zirconia copings were fabricated, ten for each finish line geometry $(n=10)$. Each resin die was scanned for its own Zirconia coping with the Cerec-3 infra-red camera, restorations were designed with the Inlab 3.88 software and finally milled with the InLab MC XL milling unit of the CEREC InLab CAD/CAM System (Cerec 3; Sirona Dental Systems GmbH, Bensheim, Germany). The coping thickness was adjusted according to average manufacturers' recommendations to be $0.5 \mathrm{~mm}$ occlusal and midaxial for all groups ending with the suitable margin according to the corresponding die's finish line and with a cement space of $35 \mu \mathrm{m}$ [42]. The milled cores were sintered in high-temperature furnace Infire HTC speed sintering furnace (Cerec 3; Sirona 
Dental Systems GmbH, Bensheim, Germany) for 90 minutes at $1540{ }^{\circ} \mathrm{C}$. After sintering process the copings were adjusted for perfect fit on their corresponding dies. The fitting surfaces of the copings of all groups were air abraded (Basic classic; Renfert GmbH, Hilzingen, Germany) with $100 \mu \mathrm{m}$ aluminium oxide $\left(\mathrm{Al}_{2} \mathrm{O}_{3}\right)$ [43] at 2 bar from $10 \mathrm{~mm}$ and for 10 seconds [44].

\section{Cementation and fracture resistance test:}

Each finish line group was divided to two subgroups $(\mathrm{n}=5)$ each, in the first subgroup the copings were cemented with glass ionomer cement (GC Fuji I, GC corporation, Tokyo, Japan) and the second subgroup was cemented with self adhesive dual cured resin cement (G-Cem, GC corporation, Tokyo, Japan), Both cements were activated and mixed for 10 seconds according to the manufacturer's instructions. The copings with extruded cement inside were then seated on the corresponding dies, excess cement was removed then the copings were loaded with a vertical load of $1 \mathrm{~kg}$ for 10 minutes using a loading device to ensure complete seating. The margins of the resin cemented copings were light cured for 20 seconds on each side to ensure complete setting. Specimens were stored in distilled water at room temperature for 48 hours [41] before testing. Two strain gauges (BCD 300 A,KYOWA, Tokyo, Japan) of $1 \mathrm{~mm}$ length were bonded one on the buccal and one on the lingual surfaces of the coping $1 \mathrm{~mm}$ above the margin (the beveled surface was named as the buccal one). To measure the FR of the $\mathrm{ZrO}_{2}$ copings they were subjected to vertical loading in a universal testing machine (LRX-plus;LloydinstrumentsLtd., Fareham,UK) with a load cell of 5 Kilonewton (KN) till fracture occurred, The loading piston was centered on the coping's occlusal surface until catastrophic fracture occurred (Figure 2). The loading piston was a vertically movable rod with semispherical loading surface of $5 \mathrm{~mm}$ in diameter and speed of $0.5 \mathrm{~mm} / \mathrm{min}$ [45]. The strain gauges lead wires were connected to a Strain Meter (BCD
300 A, KYOWA, Tokyo, Japan ) to measure the strain induced in the samples from the moment of load application till failure occurred. The fragments of each specimen were retrieved and failed specimens were examined for assessment of mode of failure. Examination was done with digital microscope (Dino-Lite Pro II, Olympus, Tokyo, Japan). Statistical analysis of the obtained data was performed using SPSS version 20 (Statistical Package for Scientific Studies 19.0, IBM, Chicago, IL, USA) for Windows. Initially descriptive statistics for each group results were held. Fracture load data, in N, were analyzed with a 2-way analysis of variance (ANOVA) $(\mathrm{p}<.05)$ to assess the effect of finish line configuration and cement used over FR and strain.

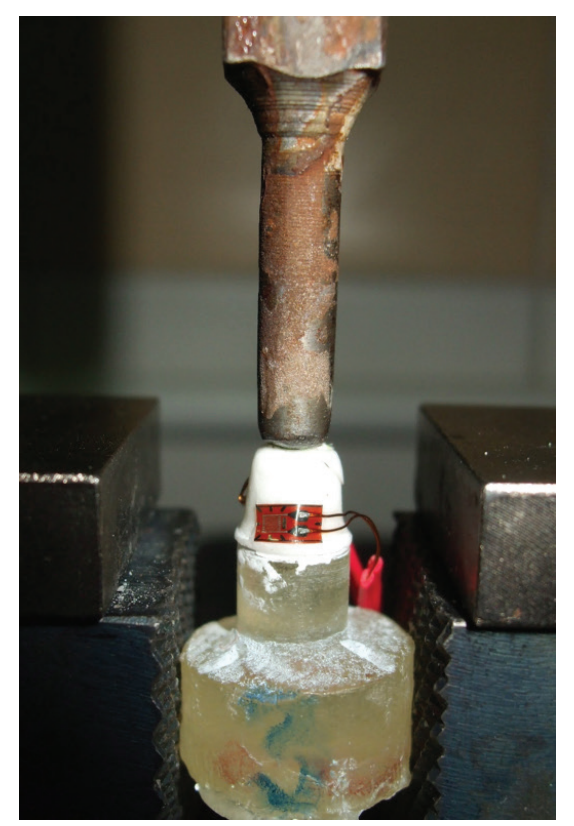

Figure 2 - Loading to fracture with the strain gauge cemented on the zirconia coping buccal and lingual.

\section{RESULTS}

Statistical analysis of FR results measured in Newton $(\mathrm{N})$ and strain measured in $(\mu \mathrm{m} / \mathrm{m})$ for different finish line configurations and different cements were held.

\section{-Descriptive statistics:}

Fracture resistance: 
The data showed that KNE had the highest mean FR (987.04 \pm 94.18$)$ followed by $\mathrm{CH}$ finish line (883.28 \pm 205.42$)$ then S finish line $(828.64$ $\pm 227.79)$ and finally the DCH finish line (767.66 \pm 207.09 ) (Figure 3). The data also showed that resin cemented copings (R) had higher mean FR $(911.76 \pm 167.95)$ than the glass ionomer (GI) cemented copings (821.55 \pm 224.24$)$ (Figure 3).

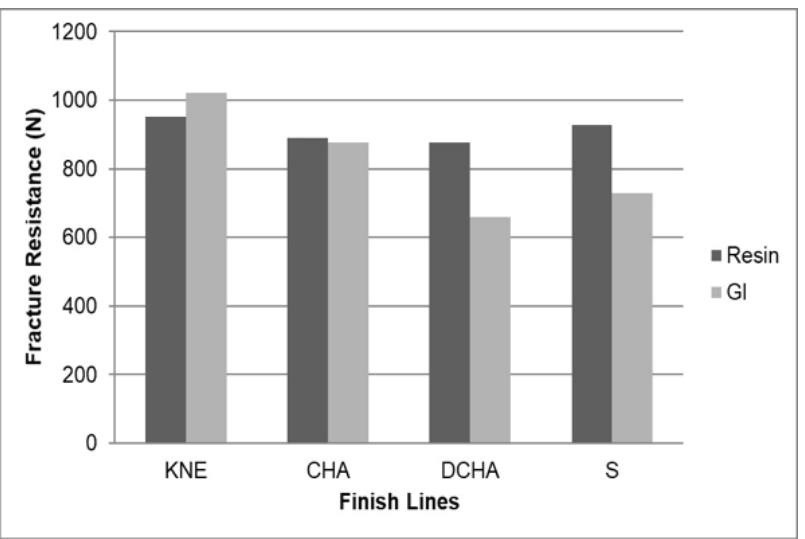

Figure 3 - A column chart of fracture resistance mean values for all finish line groups with different cement types.

\section{Strain analysis:}

The buccal strain for all finish lines was higher than the lingual. The data showed that regarding buccal strain the KNE had the highest mean strain values $(374.04 \pm 195.43)$ followed by $\mathrm{CH}(226.89 \pm 96.60)$, DCH (159.96 \pm 44.21$)$ and finally $S$ finish line (127.47 \pm 40.32). Regarding lingual strain, KNE had the highest mean strain values $(235.80 \pm 103.46)$ followed by the DCH (137.51 \pm 46.14$)$, CH (133.63 and \pm $71.35)$ and finally $S$ finish line $(68.35 \pm 80.68)$. The data showed that resin cemented $(\mathrm{R})$ copings had higher buccal and lingual mean strain values $(295.05 \pm 167.92)(197.38 \pm 99.85)$ than glass ionomer cemented (GI) copings (149.14 \pm 60.94) (90.27 \pm 55.62). (Figure 4)

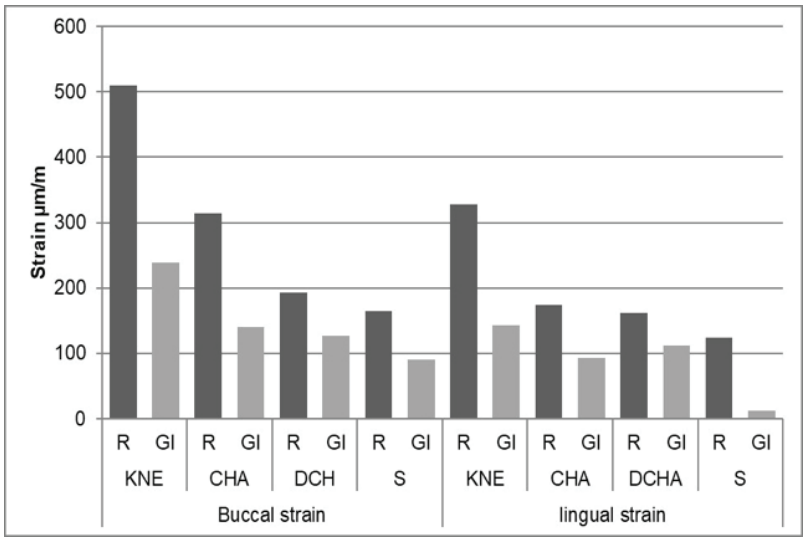

Figure 4 - A column chart of mean buccal and lingual strain values for different finish lines with different cements.

\section{- Two-Way ANOVA:}

Two-Way ANOVA for repeated measures was used to identify significance between groups. It showed that neither finish line configuration, nor cement type or any of their interactions had a statistically significant effect over FR of zirconia copings (Table I).

Table I - Two-Way ANOVA for the effect of finish line configurations, cement type and their interactions on the fracture resistance of TZP copings

\begin{tabular}{|c|ccccc|}
\hline Source & $\begin{array}{c}\text { Type IIISum of } \\
\text { Squares }\end{array}$ & df & $\begin{array}{c}\text { Mean } \\
\text { Square }\end{array}$ & F & Sig. \\
\hline Corrected Model & $490524.447 \mathrm{a}$ & 7 & 70074.921 & 2.072 & 0.076 \\
\hline Intercept & 30043635.56 & 1 & 30043635.6 & 888.356 & 0 \\
\hline Finish line & 260140.891 & 3 & 86713.63 & 2.564 & 0.072 \\
\hline cement & 81378.441 & 1 & 81378.441 & 2.406 & 0.131 \\
\hline $\begin{array}{c}\text { Finish line }^{*} \\
\text { cement }\end{array}$ & 149005.115 & 3 & 49668.372 & 1.469 & 0.242 \\
\hline Error & 1082220.172 & 32 & 33819.38 & & \\
\hline Total & 31616380.18 & 40 & & & \\
\hline Corrected Total & 1572744.619 & 39 & & & \\
\hline
\end{tabular}

a. R Squared $=.312$ (Adjusted R Squared $=.161$ ) *Significant at $p<0.05$ 
Two-Way ANOVA was used to identify significance between buccal and lingual strain within the same subjects, the buccal strain was higher than the lingual strain and the mean difference was statistically significant, the test also showed that different finish line types, different cements types and any of finish lines cements interactions had no effect on that significant difference.

Table II - Two-Way ANOVA for repeated measures showing the effect of finish lines, cements and their interactions on the buccal and lingual strain

\begin{tabular}{|c|c|cccc|}
\hline Source & $\begin{array}{c}\text { Type IIIS Sum of } \\
\text { Squares }\end{array}$ & df & $\begin{array}{c}\text { Mean } \\
\text { Square }\end{array}$ & F & Sig. \\
\hline Strain & 122514.466 & 1 & 122514.466 & 23.198 & $0.00^{*}$ \\
\hline strain * finishline & 36517.346 & 3 & 12172.449 & 2.305 & 0.096 \\
\hline $\begin{array}{c}\text { strain * cement } \\
\text { strain * finishline * } \\
\text { cement }\end{array}$ & 7529.916 & 1 & 7529.916 & 1.426 & 0.241 \\
\hline Error(strain) & 14816.687 & 3 & 4938.896 & 0.935 & 0.435 \\
\hline
\end{tabular}

*Significant at $p<0.05$

\section{Mode of failure:}

All specimens showed cohesive failure of the zirconia coping (100\%) (Table III). The (R) copings showed a predominant type of cohesive failure of the epoxy resin die (90\%) and adhesive failure btween the cement and the zirconia in (75\%) of the samples (Figure 5 ). The (GI) copings showed a predominant type of mixed adhesive failure of the cement with the epoxy resin die and the internal surface of zirconia copings (65\%). while none of the specimens showed cohesive failure of the die (0\%) (Figure 6).

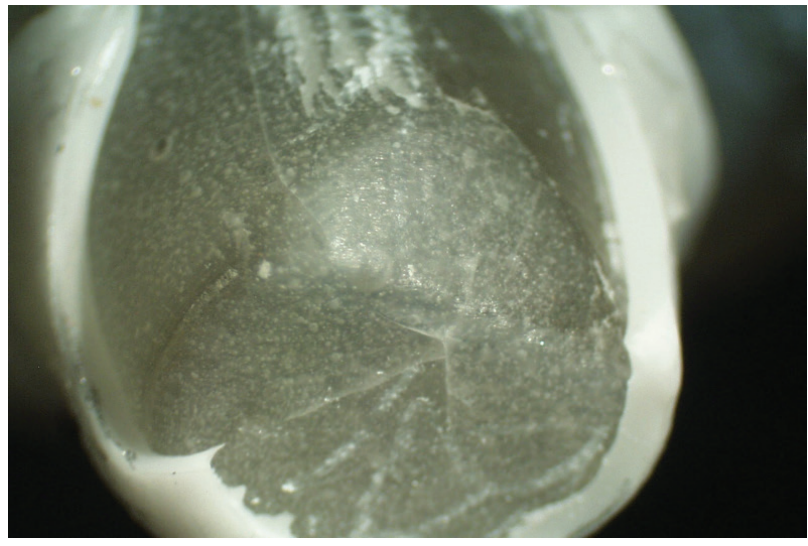

Figure 5 - Stereomicroscopic images of failed resin cemented zirconia copings showing the cracked die and adherent resin cement.

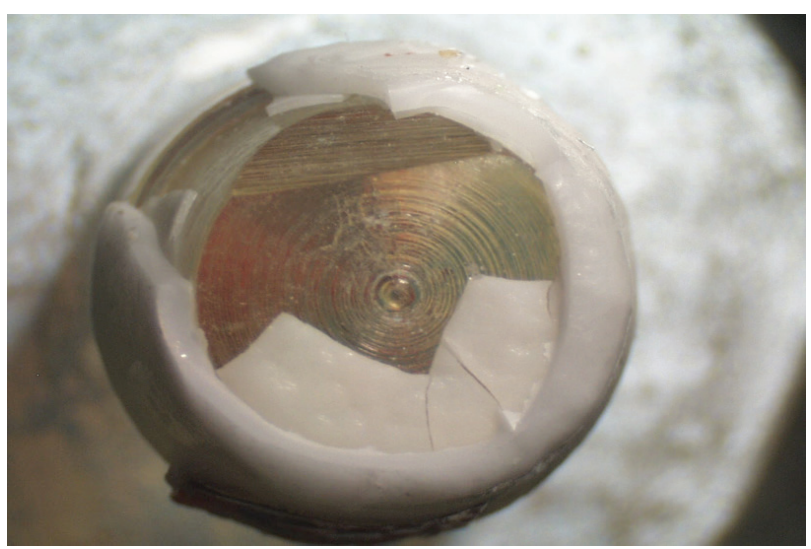

Figure 6 - Stereomicroscopic images of failed conventionally cemented zirconia copings showing the mixed adhesive failure.

Table III - Number of specimens and percentage (\%) of each failure type in the two cement groups

\begin{tabular}{|c|c|c|c|c|c|}
\hline & \multicolumn{2}{|c|}{ Cohesive failure } & \multicolumn{3}{|c|}{ Adhesive failure of cement } \\
\hline & Coping & Die & $\begin{array}{l}\text { With the } \\
\text { die }\end{array}$ & $\begin{array}{l}\text { With the } \\
\text { coping }\end{array}$ & Mixed \\
\hline RCopings & $20 / 20(100 \%)$ & $\begin{array}{l}18 / 20 \\
(90 \%)\end{array}$ & 0/20(0\%) & $\begin{array}{l}15 / 20 \\
(75 \%)\end{array}$ & $\begin{array}{l}5 / 20 \\
(25 \%)\end{array}$ \\
\hline GI Copings & $20 / 20(100 \%)$ & $\begin{array}{l}0 / 20 \\
(0 \%)\end{array}$ & $7 / 20(35 \%)$ & $0 / 20(0 \%)$ & $\begin{array}{l}13 / 20 \\
(65 \%)\end{array}$ \\
\hline
\end{tabular}




\section{DISCUSSION}

In this study the results support acceptance of the two fold null hypothesis that FR of $\mathrm{ZrO}_{2}$ copings didn't differ with different finish line designs or cement types. The evolution in dental materials adhesive technologies have led to interest in Minimally Invasive Dentistry with maximum preservation of tooth structure [14]. So the purpose of this study was to evaluate whether high strength $\mathrm{ZrO}_{2}$ core materials were suitable for different finish line preparations, and how changing the cement type influenced the resulting FR and strain analysis of in vitro prepared copings. The results of this study showed that regarding the effect of finish line on FR of $\mathrm{ZrO}_{2}$ copings, the $\mathrm{KNE}$ finish line showed the highest mean FR followed by $\mathrm{CH}$ finish line then $\mathrm{S}$ and finally DCH finish line but the difference wasn't statistically significant. These results may be attributed to the amount of remaining supporting structure as the KNE and $\mathrm{CH}$ may have higher FR because of the increased amount of remaining supporting die structure. The results obtained from this study are in accordance with other studies, Beuer et al. [41] who reported insignificant higher FR of KNE finish line than $\mathrm{S}$ finish line which had higher mean FR than $\mathrm{CH}$ and DCH significantly. The favorable results of the KNE preparation was explained as when applied load on the coping was increased, the coping could slide down the axial wall of the die without being limited by the margin. This then resulted in a stress concentration on the occlusal surface of the coping [41] and this also may explain the reason why the GI cemented copings had higher FR than R copings in the KNE group only, as the glass ionomer may had facilitated this sliding movement of the coping over the finish line more than resin cement did. The favorable results of S finish line compared to DCH was explained that the occlusal forces were directed perpendicular on the circumferential $\mathrm{S}$ margin, and there was less stress concentration on the axial walls compared to $\mathrm{CH}$ margin [41]. Reich et al. [13] reported a significant higher mean FR of $\mathrm{ZrO}_{2}$ copings of KNE preparations over $\mathrm{CH}$ preparations. The results of this study showed higher FR of S over DCH preparations. This may be attributed to the increased cervical thickness of the S margin [38]. Mitov et al. [46] showed higher fracture resistance of monolithic zirconia crowns with $\mathrm{KNE}$ margin over $\mathrm{CH}$ and $\mathrm{DCH}$ although he did not recommend clinical application of KNE due to periodontal considerations. As a contradictive result; Skjold et al [25] concluded that $\mathrm{ZrO}_{2}$ crowns made for a $\mathrm{CH}$ preparation fracture at significantly higher loads than similar crowns made for a slice preparation design but both at loads above normal mastication forces and referred that to increased thickness. A. Ahmadzadeh [2] and Jalalian et al. [42] compared the effect of DCH and $\mathrm{S}$ finish lines on the $\mathrm{FR}$ of $\mathrm{ZrO}_{2}$ copings and found that the DCH preparation copings' FR was significantly higher than S preparation, and referred that to the rounded internal angle of DCH. Regarding the cement type; the results of this study showed that the $\mathrm{R}$ copings of all finish line groups -except KNE finish line- had higher mean FR than the GI copings and the difference showed no statistical significance. This may be attributed to strengthening effect of the resin cement by filling the pores and defects in the fitting surface of the coping and better force distribution [33]. As there is a difference in the modulus of elasticity between the two cements used, resin cement with modulus of elasticity closer to that of the die material and dentin is believed to transfer stress more effectively between the stiff coping and the supporting structure [13,39] and that was confirmed by the results of the mode of failure as most of the $\mathrm{R}$ copings showed abutment fracture or cracking suggesting direct load forces transfer to the underlying structure compared to GI copings. Casson et al. [29] explained the lower FR of GI copings by the glass ionomer cement's creep and interfacial 
delamination under vertical load. These results are in accordance with Tinschert et al.[3] Ernst et al.[26] Bindl et al. [24] and Rosentritt et al. [47] The strain measurements results of this study supported the FR results as the strain was higher in less invasive finish lines because thinner margins are more prone to flexion and displacement than thicker ones [48]. The higher buccal strain values over the lingual in all groups were attributed to the bevel which may have concentrated the stresses and affected the strain magnitude. The higher strain values in $\mathrm{R}$ copings group than GI copings group may be attributed to the better adhesive and mechanical properties of resin cement causing the marginal areas to withstand higher strain values before failure. Moreover, shrinkage of resin cement during setting may have caused stresses in the cervical margins of the copings with the effect being more obvious in thin margins [1].

Among the limitations of this study that dies and crown forms were fabricated with a flat occlusal morphology to achieve precision and reproducibility. The effect of fatigue and the presence of saliva may also be taken into consideration in future research.

\section{CONCLUSION}

1. Vertical knife edge finish line showed comparable fracture resistance with horizontal finishlines in $\mathrm{ZrO}_{2}$ copings.

2. There is no evidence that the cementaion protocol either resin or glass ionomer affect the fracture resistance of $\mathrm{ZrO}_{2}$ copings.

3. More conservative finish lines configurations copings measured the highest strain values before fracture.

\section{Funding}

The authors received no financial support for the research, authorship, and/or publication of this article.

\section{Conflict of interest}

The authors have no proprietary, financial, or other personal interest of any nature or kind in any product, service, and/or company that is presented in this article.

\section{REFERENCES}

1. De Jager N, Pallav P, Feilzer AJ. The influence of design parameters on the FEA-determined stress distribution in CAD-CAM produced all-ceramic dental crowns. Dent Mater 2005;21(3):242-51. doi: 10.1016/j. dental.2004.03.013

2. Ahmadzadeh A, Golmohammadi F, Mousavi N. Effect of marginal design on fracture resistance of IPS e.max all ceramic restorations: chamfer versus shoulder finish lines. J Islam Dent Assoc Iran 2015;27,(2):64-9.

3. Tinschert J, Natt G, Mautsch W, Augthun M, Spiekermann H. Fracture resistance of lithium disilicate, alumina and zirconia based three-unit fixed partial dentures: a laboratory study. Int J Prosthodont 2001;14(3):231-8. PMID: 11484570 .

4. Conrad HJ, Seong WJ, Pesun IJ. Current ceramic materials and systems with clinical recommendations: a systematic review. J Prosthet Dent 2007;98(5):389-404. doi:10.1016/S0022-3913(07)60124-3.

5. Christel P, Meunier A, Heller M, Torre JP, Peille CN. Mechanical properties and short-term in-vivo evaluation of yttrium-oxide-partiallystabilized zirconia. J Biomed Mater Res 1989;23(1):45-61. doi: 10.1002/ jbm.820230105.

6. Piconi C, Maccauro G. Zirconia as a ceramic biomaterial. Biomaterials 1999;20(1):1-25. doi: 101016/s0142-9612(98)00010-6.

7. Raigrodski AJ. Contemporary materials and technologies for all-ceramic fixed partial dentures: a review of the literature. J Prosthet Dent 2004;92(6):557-62. doi: 10.1016/j.prosdent.2004.09.015.

8. Andreiotelli M, Kohal RJ. Fracture strength of zirconia implants after artificial aging. Clin Implant Dent Relat Res 2009;11(2):158-66. doi: 10.1111/j.1708-8208.2008.00105.x.

9. Heuer AH, Lange FF, Swain MV, Evans AG. Transformation toughening: an overview. J Am Ceram Soc 1986; 69(3):i-iv. doi: 10.1111/j.1151-2916.1986. tb07400.x

10. Denry I, Kelly JR. State of the art of zirconia for dental applications. Dent Mater 2008;24(3):299-307. doi: 10.1016/j.dental.2007.05.007.

11. Potiket N, Chiche G, Finger IM. In vitro fracture strength of teeth restored with different all-ceramic crown systems. J Prosthet Dent 2004;92(5):4915. doi: 10.1016/j.prosdent.2004.09.001.

12. Rekow ED, Harsono M, Janal M, Thompson VP, Zhang G. Factorial analysis of variables influencing stress in all-ceramic crowns. Dent Mater 2006;22(2):125-32. doi: 10.1016/j.dental.2005.04.010. 
13. Reich S, Petschelt A, Lohbauer U. The effect of finish line preparation and layer thickness on the failure load and fractography of ZrO2 copings. J Prosthet Dent 2008;99(5):369-76. doi: 101016/S0022-3913(08)60085-2

14. Christensen GJ. The advantages of minimally invasive dentistry. J Am Dent Assoc 2005;136(11):1563-5. doi: 10.14219/jada.archive.2005.0088.

15. Aboushelib MN. Fatigue and fracture resistance of zirconia crowns prepared with different finish line designs. J Prosthodont 2012;21(1):22-7. doi: 10.1111/j.1532-849X.2011.00787.x.

16. Tinschert J, Natt G, Hassenpflug S, Spiekermann H. Status of current CAD/ CAM technology in dental medicine. Int J Comput Dent 2004;7(1):25-45. PMID: 15317306.

17. Von Steyern PV, Jonsson 0, Nilner K. Five-Year evaluation of posterior AllCeramic three-unit (In-Ceram) FPDs. Int J Prosthodont 2011;14(4):379-84 PMID: 11508096.

18. Pilathadka S, Vahalova D, Vosahlo T. The zirconia: a new dental ceramic material. an overview. Prague Med Rep 2007;108(1):5-12. PMID: 17682722.

19. Shillingburg $H T$, Hobo S, Whitsett LD, Jacobi R, Brackett SE. principles of tooth preparation. In: Fundamentals of fixed prosthodontics. 4th ed. Chicago: Quintessence; 2012. p.131-48.

20. Goodacre CJ, Campagni WV, Aquilino SA. Tooth preparations for complete crowns: an art form based on scientific principles. J Prosthet Dent 2001;85(4):363-76. doi: 10.1067/mpr.2001.114685.

21. Pardo Gl. A full cast restoration design offering superior marginal characteristics. J Prosthet Dent 1982;48(5):539-43. doi: 10.1016/00223913(82)90358-4.

22. Sannino G, Gloria F, Ottria L, Barlattani A. Influence of finish line in the distribution of stress through an all ceramic implant supported crown. A3D Finite Element Analysis. J Oral Implantol 2009;2(2):14-27. PMCID: PMC3415351.

23. Schmitt J, Wichmann M, Holst S, Reich S. Restoring severely compromised anterior teeth with zirconia crowns and featheredged margin preparations: a 3-year follow-up of a prospective clinical trial. Int J Prosthodont 2010;23(2):107-9. PMID: 20305846.

24. Bindl A, Luthy H, Mormann WH. Thin wall ceramic CAD CAM crown copings strength and fracture pattern. J Oral Rehabil 2006;33(7):520-8. doi: 10.1111/j.1365-2842.2005.01588.x.

25. Skjold A, Schriwer C, Oilo M. Effect of margin design on fracture load of zirconia crowns. Eur J Oral Sci 2019;127(1):89-96. doi: 10.1111/eos.12593.

26. Ernst CP, Cohnen U, Stender E, Willershausen B. In vitro retentive strength of zirconium oxide ceramic crowns using different luting agents. J Prosthet Dent 2005;93(6):551-8. doi: 10.1016/j.prosdent.2005.04.011.

27. Burke FJ, Fleming GJ, Nathanson D, Marquis PM. Are adhesive technologies needed to support ceramics? An assessment of the current evidence. J Adhes Dent 2000;4(1):7-22. PMID: 12071631.

28. Rosenstiel SF, Land MF, Cripson BJ. Dental luting agents: a review of the current literature. J Prosthet Dent 1998;80(3):280-301. doi: 10.1016/s00223913(98)70128-3.

29. Casson AM, Glyn Jones JC, Youngson CC, Wood DJ. The effect of luting media on fracture resistance of a flame sprayed all-ceramic crown. J Dent 2001;29(8):539-44. doi:10.1016/s0300-5712(01)00040-9.

30. Blatz MB, Chiche G, Holst S, Sadan A. Influence of surface treatment and simulated aging on bond strengths of luting agents to zirconia. Quintessence Int 2007;38(9):745-53.PMID: 1787398
31. Blatz MB, Sadan A, Martin J, Lang B. In vitro evaluation of shear bond strengths of resin to densely-sintered high-purity zirconium-oxide ceramic after long-term storage and thermal cycling. J Prosthet Dent 2004:91(4):356-62. doi: 10.1016/j.prosdent.2004.02.001.

32. Atsu SS, Kilicarslan MA, Kucukesmen HC, Aka PS. Effect of zirconiumoxide ceramic surface treatments on the bond strength to adhesive resin. J Prosthet Dent 2006;95:430-6. doi:10.1016/j.prosdent.2006.03.016.

33. Magne P.Composite resins and bonded porcelain: the postamalgam era? Calif Dent Assoc 2006;34(2):135-47. PMID: 16724469.

34. Mahler DB, Peyton FA. Photoelasticity as research technique for analyzing stresses in dental structures. J Dent Res 1955;34(6):831-8. doi: 10.1177/00220345550340060601.

35. Johnson EW, Castaldi CR, Gau DJ, Wysocki GP. Stress pattern variations in operatively prepared human teeth, studied by threedimensional photoelasticity. J Dent Res 1968; 47 (4):548-58. doi: 10.1177/00220345680470040601.

36. El-Ebrashi MK, Craig RG, Peyton FA. Experimental stress analysis of dental restorations VII. Structural design and stress analysis of fixed partial dentures. J Prosthet Dent 1970; 23 (2):177-86. doi: 10.1016/00223913(70)90295-7.

37. Datte CE, Rodrigues VA, Datte FB, Lopes GRS, Borges ALS, Nishioka RS. The effect of different bone level and prosthetic connection on the biomechanical response of unitary implants: strain gauge and finite element analyses. IRJAES 2021; 8(2), 218-224. doi: 10.22161/ijaers.82.28.

38. Di lorio D, Murmura G, Orsini G, Scarano A, Caputi S. Effect of margin design of the fracture resistance of procera All-Ceram cores: an in vitro study. J Contemp Dent Pract 2008;9(2):1-8. PMID: 18264519.

39. Chun Lia Z, White SN. Mechanical properties of dental luting cements. J Prosthet Dent 1999;81(5):597-609. doi: 10.1016/s0022-3913(99)70216-7.

40. Souza RO, Ozcan M, Pavanelli CA, Buso L, Lombardo GH, Michida SM et al. Marginal and internal discrepancies related to margin design of ceramic crowns fabricated by a CAD/CAM System. J Prosthodont 2012;21(2):94100. doi: 10.1111/j.1532-849X.2011.00793.x.

41. Beuer $F$, Aggstaller $H$, Edelhoff $D$, Gernet W. Effect of preparation design on the fracture resistance of zirconia crown copings. Dent Mater 2008;27(3):362-7. doi: 10.4012/dmj.27.362.

42. Jalalian E, Atashkar B, Rostami R. The effect of preparation design on the fracture resistance of zirconia crown copings (Computer Associated Design/Computer Associated Machine, CAD/CAM System). J Dent (Tehran) 2011;8(3):123-9. PMID:22457839.

43. Dino R, Davide A, Irena S, Diego $S$, Antonio C. The effect of the surface treatment on the adhesion of resin cements to Y-TZP.Eur J Esthet Dent 2008;3(2):186-96. PMID: 19655531.

44. Stawarczyk B, Ozcan M, Hallmann L, Roos M, Trottmann A, Hammerle $\mathrm{CH}$. Impact of air-abrasion on fracture load and failure type of veneered anterior Y-TZP crowns before and after chewing stimulation. J Biomed Mater Res B Appl Biomater 2012;100(6):1683-90. doi: 10.1002/jbm.b.32737.

45. Akesson J, Sundh A, Sjogren G. Fracture resistance of all-ceramic crowns placed on a preparation with a slice-formed finishing line. J Oral Rehabil 2009;36:516-23. doi:https://doi.org/10.1111/.j1365-2842.2009.01962.x.

46. Mitov G, Anastassova-Yoshida Y, Nothdurft FP, von See C, Pospiech P. Influence of the preparation design and artificial aging on the fracture resistance of monolithic zirconia crowns. J Adv Prosthodont. 2016;8(1):30 36. doi: 10.4047/jap.2016.8.1.30. 
47. Rosentritt M, Hmaidouch R, Behr M, Handel G, Schneider-Feyrer S. Fracture resistance of zirconia FPDs with adhesive bonding versus conventional cementation. Int J Prosthodont 2011;24(2):168-71.PMID: 21479286
48. Shinya A, Lassila VJ, Vallittu PK. The effect of preparation design on the marginal stress of resin-bonded metal-free crowns: a finite element study. Int J Prosthodont 2008;21(5):445-7.

\section{Marwa Emam}

\section{(Corresponding address)}

Faculty of Dentistry, Ain Shams University, Organization of African Unity St, El-Qobba Bridge, Al Waili, 11566, Cairo, Egypt.

Email: marwaemam@asfd.asu.edu.eg

Date submitted: 2020 Sep 24

Accept submission: 2021 Jan 13 